\title{
All it Takes is One Click to Join Me on a "Meet": The Positive Impact of Technology on Peer Observations in the Virtual Learning Environment
}

Jamie Silverman

Towson University, jsilverman@towson.edu

Follow this and additional works at: https://digitalcommons.georgiasouthern.edu/cimle

Part of the Curriculum and Instruction Commons, and the Junior High, Intermediate, Middle School Education and Teaching Commons

\section{Recommended Citation}

Silverman, Jamie (2020) "All it Takes is One Click to Join Me on a "Meet": The Positive Impact of Technology on Peer Observations in the Virtual Learning Environment," Current Issues in Middle Level Education: Vol. 25 : Iss. 2 , Article 9. DOI: $10.20429 /$ cimle.2021.250209

Available at: https://digitalcommons.georgiasouthern.edu/cimle/vol25/iss2/9

This description is brought to you for free and open access by the Journals at Digital Commons@Georgia Southern. It has been accepted for inclusion in Current Issues in Middle Level Education by an authorized administrator of Digital Commons@Georgia Southern. For more information, please contact digitalcommons@georgiasouthern.edu. 


\title{
All It Takes is One Click to Join Me on a "Meet": The Positive Impact of Technology on Peer Observations in the Virtual Learning Environment
}

\author{
Jamie Silverman \\ Towson University
}

\begin{abstract}
Physically stepping foot into the middle and high school classroom is the opportunity teacher candidates (TCs) most look forward to as they enter their final year in our middle and secondary teacher preparation program. It is in this internship year when TCs practice the theory they have learned and start making their own pedagogical choices. The internship year and its experiences are recognized by AMLE Standard 1: "Middle level teacher candidates understand, use, and reflect on the major concepts, principles, theories, and research related to young adolescent development and use that knowledge in their practice" (AMLE, 2012). The question I faced with the arrival of COVID-19 and the shutdown of in-person school this past spring and fall as a teacher educator (TE) was this: How will I be able to provide these valuable moments of professional growth for my TCs if they are not in the buildings? The following description presents fellow teacher educators with my response to this question. I describe the creation of virtual peer observation experiences and in-real-time coaching that occurred in the virtual internship. Additionally, I describe the impact this process had on virtual post-observation conferences.
\end{abstract}

\section{Embracing the Virtual Internship via Opportunities to Access Technology}

I had no choice. In a field where I so often teach my teacher candidates (TCs) about the importance of it, I, as their teacher educator had no choice. Schools were shut down and my TCs now had to teach in a completely virtual online learning environment and my observations of the TCs would also be completed virtually. Peer observations, which traditionally call on TCs to enter each other's classrooms would now also present a challenge. But there was one belief that my fellow teacher educators and I in the Department of Middle and Secondary Education at my university would not compromise: The integrity of my TCs' internship year and the knowledge gained in the areas of planning, instruction, assessment and community building (to name a few) would not fall to wayside because the classroom environment shifted. Frost and Frost (2020) remind us that "delivering classes online in a significant way is a first for many educators, and a certain amount of stress naturally follows whenever someone is forced to change by uncontrollable event" (p. 2). They reiterate the anxiety that I was feeling when I realized my TCs would never enter a physical classroom this past fall, but the importance of being a reflective 
practitioner to continue to improve upon these skills would not be lost on these TCs. After all, as Slade et. al (2019) remind us, "perhaps the most promising aspect of using reflective practice in teacher preparation is the potential for enhancing students' acquisition of knowledge and skills" (p.6).

To engage the TCs in meaningful observations and facilitate peer observations in this new environment I needed to embrace the technology we were now immersed in daily. Benson and Cotabish (2014) comment that "utilizing new and innovative technology to provide immediate feedback to teacher candidates can serve as a significant improvement to teacher education programs" (p. 6). In the traditional internship, the demand on my time as a teacher educator and supervisor to travel from classroom to classroom often forced me to lead postobservation conferences a day or two following a formal observation. However, now that my TCs were teaching via Google Meets I was able to quickly travel from one classroom to the next and to return back to a classroom to run a post-observation with a simple click. The ability to engage my TCs in a virtual post-observation conference within minutes of them completing their observation lesson resulted in a more timely and effective reflection with my TCs about the strengths and weaknesses of their instruction that day. I agree with Benson and Cotabish (2104) that "on demand feedback immediately redirects teaching behaviors before poor instructional practices have the opportunity to become poor instructional habits" (p. 7).

In addition to the gift of time resulting from observing my TCs in a virtual learning environment, I was also ready to embrace the ability to invite their peers into their virtual classrooms to engage with me and the TC in a reflective in-real-time observation of their peers' teaching and to allow them to join our post-observation conferences. I refer to this as peer coaching. I believe that as important as it is for TCs to teach and learn from this experience, it is equally important to observe and unpack peer pedagogical decision making to improve performance. Lewis and Jones (2019) shed light on the importance of technology to enhance this process when they state that "as the technology to provide digital coaching continues to evolve, additional opportunities to refine skill development in this regard are possible" (p. 16). TCs were afforded the opportunity to observe multiple peers over the course of the virtual internship and thus given the opportunity to take part in multiple virtual coaching sessions with the teacher educator. This technology removed the barrier of distance and allowed more TCs to receive the benefits and increased amount of coaching interactions (Benson \& Cotabish, 2014).

Another moment to embrace technology presented itself with the opportunity for my TCs to observe their peers who taught in different schools. My cohort is split across four different schools. TCs teach in one of two middle schools and in one of two high schools. In a traditional internship my TCs would never have the time nor the opportunity to drive to the other middle or high school to observe a peer. Lewis and Jones (2019) remind us of the benefits of traveling to a school miles away with a click of button as they conclude that "opportunities to observe across grade levels and content areas would provide broader coaching skill development and selfefficacy" (p. 16).

\section{The Context}

As a full-time faculty member in the Department of Secondary and Middle School Education at my University, I act also as a Professional Development School (PDS) Liaison. As a PDS Liaison, I oversee a cohort of 12 middle and secondary TCs each year. In addition to teaching them twice a week in their part-time internship, I also act as their supervisor and 
observe each intern four times over the course of their part-time internship. The part-time internship traditionally calls on TCs to report to their schools two days a week for three hours each day. Due to COVID-19 and the shift to virtual learning, our College made changes to the part-time internship this fall. Instead, the part-time internship occurred over the course of 5 weeks. TCs reported to their schools in a virtual capacity five full days/week. TCs in my cohort are certified grades 7-12 in their content area. Content areas include History, English and Foreign Language. The county in which our interns completed their part-time internship accessed Google Meets as their online platform.

This current cohort of TCs have no experience teaching in a virtual environment. Their mentors do; they shifted to a virtual platform this past spring. Though mentors are more familiar with teaching in a virtual environment, the structure of this particular county's virtual classroom did shift with the return to online school this fall. Mentors had to learn how to navigate Google Meets, the platform the county adopted for online learning. An additional concern that presented was the mentors' ability to not only teach in this new platform but to mentor our TCs. To respond to this concern, I created a Google Doc schedule that outlined both the TC and associated mentor's responsibilities over the course of the 5 weeks. This would ensure that each TC experienced a similar and equally as rigorous part-time internship. I also led mentors through a mentor training on Google Meets to ease anxieties mentors were feeling as they shifted to a virtual mentoring experience.

Come the end of January 2021, my teacher candidates will report to their full-time internship where they complete an 8 week middle school and an 8 week high school rotation. The county is still operating in a virtual capacity and so my TCS will return the Google Meets platform to teach.

\section{The Peer Observation and Peer Coaching Process}

After the first round of 12 observations, I realized that now more than ever it was essential for my TCs to complete the peer observation they traditionally complete in real life. Each of the 12 classrooms I observed was so different from the next. In a traditional internship year, TCs would walk through middle and high school buildings and see and hear just how different one class is from the next. I realized that each TC only had one lens to look through and to learn about the middle and secondary classroom as a result of being virtual. Each day they signed on to their Google Meet and virtual teaching was only what they perceived it to be based on their one classroom experience.

It was important that I engage my TCs in the peer observation process. Yuksel and Basaran remind us that, "By receiving and providing feedback [from their peers], the teacher candidates can also gain a better understanding of their own learning processes" (p. 85). In this case, my TCs needed to learn from one another how to facilitate on-line learning and how to build a classroom community in a virtual learning environment. They needed to see what I was seeing. I wanted to take it further than this by engaging them in peer coaching sessions. After completing one round of observations I quickly identified what skills TCs were strong in related to planning, instructing, assessing, and classroom community building and where they fell short. Additionally, I was also able to observe which mentors were more comfortable and stronger teaching online than others. With intention, I created two rounds of peer observations TCs had to move through over the course of the observations. (See Appendix A for more information on the administrative set up of the peer observation process.) 
As TCs joined a Google Meets session for their peer, I joined to formally observe the TC but also to act as a peer coach to the TC who was observing. While the TC was teaching, their peer and I would actively time stamp the TC's pedagogical decision making. We would note what the TC was asking (or not), how they were asking questions, if they were accessing the chat, and how effective they were at doing so. We would ask each other questions back and forth via an in real time email strand. For instance, I would ask questions like, "Did you note how TC just asked a follow up question? What type of response did they get as a result? What would have happened if they did not ask or if they asked it differently? Did you note the use of praise? Was it effective? Why? Do you think that the use of a Jamboard is helping students meet the objective? Were the directions delivered clearly? What could TC do differently to make certain students understand the process?" (See Appendices B and C for more on the observation process.)

The process of observing a peer (and often a peer who taught at a different school) and engaging in a peer coaching email strand would not have been possible in a traditional internship. The virtual move to online teaching allowed me to engage my TCs in rich reflection concerning their peers" performance. Wilkins et al. (2009) argue that, "reflection and collaboration are two assets for teacher candidates in terms of growing developmentally as educators and experiencing, first-hand, qualities of professional, life-long learning" (p. 90). This experience supports this assertion. As a result of observing their peer, TCs also gained insight into their own virtual classrooms and pedagogical decision making. What could they do differently? What did they enjoy and what could they take to their classrooms to improve the classroom community and learning taking place? Though they may not have realized it at first, they too were reflecting not only on their peer's performance but on their own abilities. This was quite similar to those pre-service teachers in Yuksel and Basaran's (2020) study on reflective peer feedback in the practicum as they noted that their pre-service candidates, similar to my TCs "reflected on their performance and they either suggested the better way [to instruct] or they claimed they would adapt the same way that the peer did" (p. 105).

In addition to peer coaching, the virtual internship allowed me to invite the TCs to their peers' post observation conference. Again, with the permission of their peer, and a click of a button, both TCs were able to immediately join me for an important moment of reflection. Post observation conferences can be daunting for our TCs. By inviting a peer the environment shifted. We became a group of people who were engaging in a conversation about the teaching we just witnessed and facilitated. I often asked the TC who observed to ask questions and take the lead on the conference. I observed that the TC who taught the lesson became much less defensive of their teaching when they received feedback from a peer. Galbraith and Merril (2012) state, "there is no question that teaching effectiveness is a very personal, highly complex, and ever changing process involving a multitude of different skills and techniques" (48). When the TC heard suggestions from their peer they were able to consider it from a different lens. It wasn't offered by someone who had more experience; it was coming from someone who was in the same novice moment of teaching as they were in at the time. I was not a silent participant in these postobservation conferences. I facilitated the conversation. However, I do feel it was important that the TCs spoke more than I did in each instance. TCs were able to identify together 2-3 instructional moves they would improve (or would like to see their peer improve upon) for the next observation and they were able to celebrate 2-3 moves that should continue. All of these discussions were supported in the time-stamped email strand conversations the TC observer and I had throughout the course of the observation. The time-stamp references were an important part 
of the discussion. By referencing down to the minute and even second what their peer had done, effectively or not forced the TC to reflect based on hard data and not loose assumptions. Yuksel and Basaran (2020) suggest that the method of feedback [Teacher Educators deliver] determines how well the TCs internalize it and "thus how they reflect and develop their teaching practice accordingly" (p. 88).

\section{Becoming Professionals}

The process I describe above is supported by several AMLE Standards. AMLE Standard 5: Middle Level Professional Roles states that: "They [The TC] engage in practices and behaviors that develop their competence as middle level professionals. They are informed advocates for young adolescents and middle level education, and work successfully with colleagues, families, community agencies, and community members" (AMLE, 2012). An important lesson that I teach my TCs day one is that they are entering one of the most sacred professions and that they must always conduct themselves as ethical professionals. By engaging TCs in the peer observation process and post-observation conference, I am teaching them how to interact professionally with colleagues and developing their ability to grow as leaders and professionals in their field.

Additionally, AMLE Standard 1 states that: "Middle level teacher candidates understand, use, and reflect on the major concepts, principles, theories, and research related to young adolescent development and use that knowledge in their practice" (AMLE, 2012). Reflection occurs throughout the entire virtual peer observation process. It begins with the TCs reflecting on their peer's instructional decision making via in real time time-stamped conversation they are engaging in with me during the lesson and it continues as I shift the conversation to engage the $\mathrm{TC}$ in a reflection of their own practices compared to those we are observing. TCs reflect again with their peers in the post-observation conference that follows. One final moment of professional reflection occurs in the formal written reflection TCs are required to submit following the peer observation process. Both the TC who was observed as well as the TC who performed the peer observation write a reflection of the experience. They must discuss what they learned as a result of observing and being observed. They focus on the areas of planning, instruction and assessment as they do so and they are tasked with connecting these lessons to current educational research. TCs discuss what changes they will now make in each of these areas to become more effective secondary teachers.

Requiring TCs to connect research to their formal reflection process is another aspect of AMLE Standard 1 and it reminds them that there must be intention behind the choices they make in their planning and instructional decision making and that these intentions can be informed by others in the field. It also teaches the TCs that they must continue looking beyond their own classroom experiences to remain current in their practice. There is much to learn from those outside of their own rooms, schools, counties, states and even countries. Engaging TCs in a deep dive into the research to support their pedagogical decision making also eases anxieties related to the process itself. When TCs hear the word research they often tense up. Gregson et al. (2019) support the need for TCs to support their professional reflections with research as they suggest that, "that they (TCs) may be able to learn and engage more deeply with ideas from the research of others when that research is presented in ways which are connected to practical experience" (p. 39). 
I stated earlier that we had no choice with the arrival of COVID-19 and the shutdown of schools. However, there was one choice: to remain dedicated to these TCs and to foster their development as young professionals as they enter their own future classrooms whether they are virtual or in brick and mortal classrooms. Regardless, I am confident as a result of engaging them in these observation experiences that they will be strong reflective practitioners and more prepared middle and secondary teachers.

\section{References}

Association for Middle Level Education. (2012). Middle level teacher preparation standards with rubrics and supporting explanations. Accessed from: http://www.amle.org/AboutAMLE/ProfessionalPreparation/AMLEStandards.aspx.

Benson, T., \& Cotabish, A. (2014). Virtual Bugs: An innovative peer coaching intervention to improve the instructional behaviors of teacher candidates. SRATE Journal, 24(1), 1-9.

Craig, S. Galbraith, \& Gregory B. Merril. (2012). Predicting student achievement in universitylevel business and economics classes: Peer observation of classroom instruction and student ratings of teaching effectiveness. College Teaching. 60(2). 48. https://doi.org/10.1080/8767555.2011.627896.

Gregson, D., Gregson, M., \& Spedding, T. (2019). Top-down and outside-in: Breaking boundaries between research, theory and practice in education. Journal of Management Policy \& Practice, 20(3), 36-52. https://doi.org/10.33423/jmpp.v20i3.2229.

Frost, A., \& Frost, T. (2020). Examining supply-side benefits of virtual teaching. Ivey Business Journal, 2.

Lewis, T. E., \& Jones, K. D. (2019). Increasing principal candidates' self-efficacy through virtual coaching. Journal of Organizational and Educational Leadership, 4(3).

Slade, M. L., Burnham, T. J., Catalana, S. M., \& Waters, T. (2019). The impact of reflective practice on teacher candidates' learning. International Journal for the Scholarship of Teaching \& Learning, 13(2), 1-8. https://doi.org/10.20429/ijsotl.2019.130215.

Wilkins, E. A., Shin, E.-K., \& Ainsworth, J. (2009). The effects of peer feedback practices with elementary education teacher candidates. Teacher Education Quarterly, 36(2), 79-93.

Yüksel, İ., \& Başaran, B. Ç. (2020). Reflective peer feedback in the practicum: Qualitative and quantitative practices. Turkish Online Journal of Qualitative Inquiry, 11(1), 85-109. 


\section{Appendix A}

Administrative Tips for Peer Observation Implementation

\begin{tabular}{|c|c|}
\hline Week & Administrative Action \\
\hline Week 1 & $\begin{array}{l}\text { 1. Introduce the peer observation } \\
\text { assignment and process to both } \\
\text { the teacher candidates (TCs) } \\
\text { and the mentors so that all are } \\
\text { clear on the expectations of the } \\
\text { assignment. } \\
\text { 2. It is important that mentors } \\
\text { understand that the teacher } \\
\text { candidates' professor (in my } \\
\text { case PDS Liaison) will be } \\
\text { signing on to Google Meets } \\
\text { and will turn camera and audio } \\
\text { off immediately to remain as a } \\
\text { "ghost" observer for the } \\
\text { period. *The peer observer will } \\
\text { do the same. }\end{array}$ \\
\hline Week 2 & $\begin{array}{l}\text { 1. Observe all TCs in their } \\
\text { placements. } \\
\text { 2. Identify strengths and } \\
\text { weaknesses of each TC. (Ex. } \\
\text { Note ability to create warm on- } \\
\text { line classroom environments, } \\
\text { ability to question and listen to } \\
\text { students to offer follow-up } \\
\text { questions, ability to engage } \\
\text { students in accessing prior } \\
\text { knowledge, ability to call on } \\
\text { students by name and } \\
\text { encourage participation both in } \\
\text { the meet and in the chat box of } \\
\text { the meet.) }\end{array}$ \\
\hline & $\begin{array}{l}\text { 3. Take this time to also note the } \\
\text { differences in the mentors }\end{array}$ \\
\hline
\end{tabular}




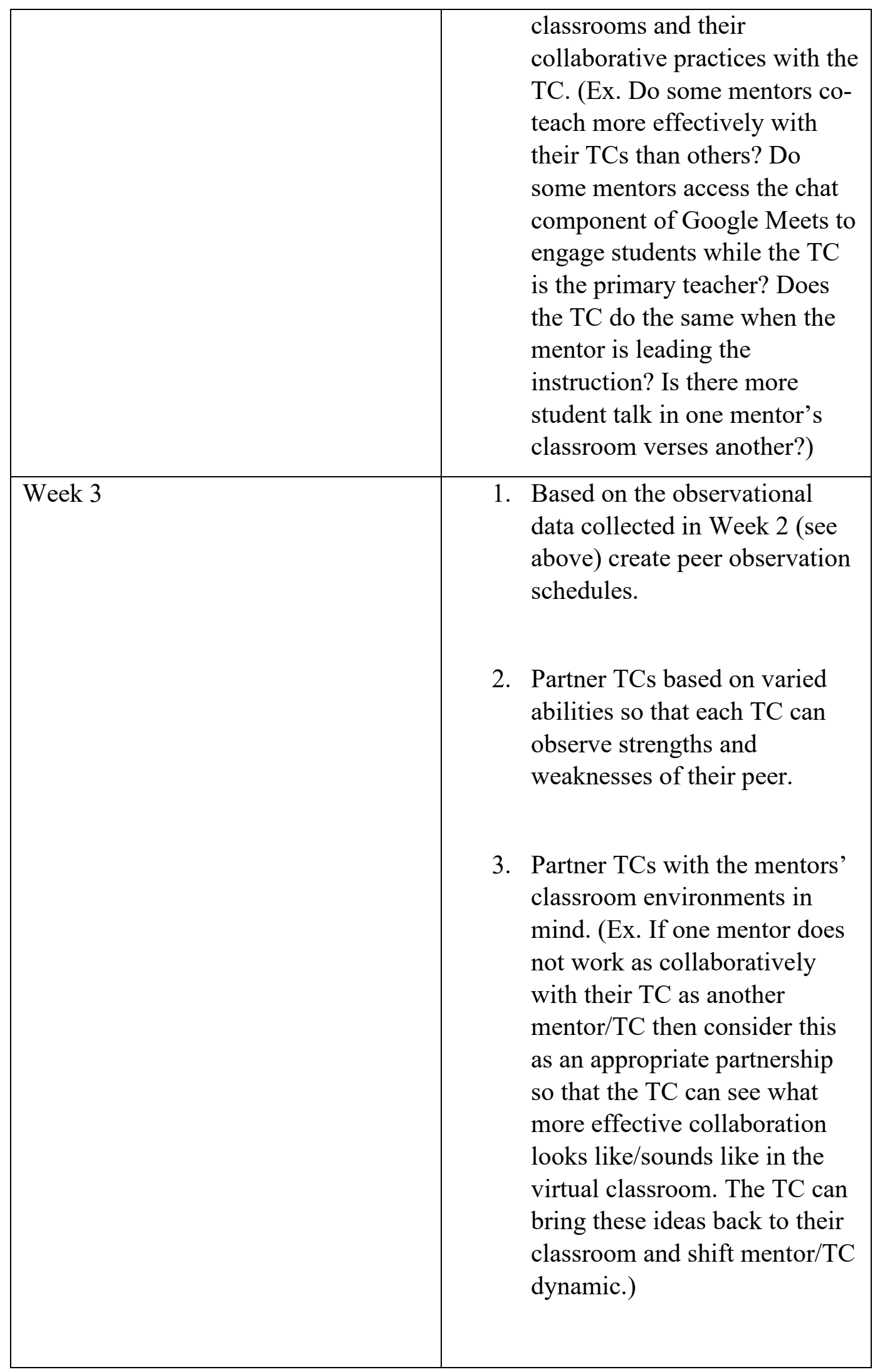




\begin{tabular}{|c|c|}
\hline & $\begin{array}{l}\text { 4. Email the mentors and TCs the } \\
\text { observation schedule at the } \\
\text { start of the week and begin } \\
\text { observations. Inform mentors } \\
\text { and TCs of the post- } \\
\text { observation conference. } \\
\text { 5. Remind them that this will } \\
\text { need to immediately follow the } \\
\text { observation on a separate } \\
\text { Google Meets. (*In } \\
\text { observations unrelated to the } \\
\text { peer observation, the mentor } \\
\text { does join our post observation } \\
\text { conference but for the purpose } \\
\text { of the peer observation } \\
\text { assignment only the TCs and } \\
\text { the Professor (PDS Liaison) } \\
\text { join. }\end{array}$ \\
\hline Week 4 & $\begin{array}{l}\text { 1. Engage TCs in Round } 2 \text { of } \\
\text { Peer Observations. }\end{array}$ \\
\hline Week 5 & $\begin{array}{l}\text { 2. Engage all TCs in a whole } \\
\text { group reflection of the peer } \\
\text { observation process. }\end{array}$ \\
\hline
\end{tabular}

*Note: This schedule can be adjusted to any length of time dependent upon the internship requirement.

\section{Appendix B}

Model Snapshot of the Peer Observation Process in Action

\begin{tabular}{|c|c|}
\hline Time & Professor Actions \\
\hline $\begin{array}{l}\text { 9:00 (5 minutes prior to the start of } \\
\text { 9:05am class): }\end{array}$ & $\begin{array}{l}\text { 1. Sign on to Google Meet. } \\
\text { Brief greeting to mentor } \\
\text { and TC being observed that } \\
\text { day. } \\
\text { 2. Brief greeting to Peer } \\
\text { Observer TC and check }\end{array}$ \\
\hline
\end{tabular}




\begin{tabular}{|c|c|c|}
\hline & 3. & $\begin{array}{l}\text { that they've signed on as } \\
\text { well. } \\
\text { Professor and peer TC } \\
\text { observer turn off video and } \\
\text { audio. }\end{array}$ \\
\hline 9:05: (Start of Class) & 1. & $\begin{array}{l}\text { Professor emails TC } \\
\text { observer to start the in real } \\
\text { time email observation } \\
\text { strand (See Appendix C for } \\
\text { suggested questions). }\end{array}$ \\
\hline \multirow[t]{4}{*}{ 9:05-9:50: (Remainder of Class) } & 1. & $\begin{array}{l}\text { Series of emails between } \\
\text { the Professor and TC } \\
\text { occur. Professor engages } \\
\text { TC observer in questions } \\
\text { concerning the TC who is } \\
\text { being observed related to } \\
\text { this TC's instructional } \\
\text { decision making. }\end{array}$ \\
\hline & 2. & $\begin{array}{l}\text { Professor makes certain to } \\
\text { highlight the skills they } \\
\text { would like the observing } \\
\text { TC to improve upon being } \\
\text { displayed with } \\
\text { effectiveness by TC who is } \\
\text { teaching. }\end{array}$ \\
\hline & 3. & $\begin{array}{l}\text { Professor encourages } \\
\text { questions by the TC } \\
\text { observer about what they } \\
\text { are observing. }\end{array}$ \\
\hline & 4. & $\begin{array}{l}\text { Professor shifts the } \\
\text { conversation by the end of } \\
\text { the lesson to the TC who is } \\
\text { observing about their own } \\
\text { past practices and how they }\end{array}$ \\
\hline
\end{tabular}




\begin{tabular}{|c|c|c|}
\hline & & $\begin{array}{l}\text { compare to their peer's } \\
\text { teaching today. }\end{array}$ \\
\hline \multirow[t]{5}{*}{ 9:50-10:20: (Following Class) } & 1. & $\begin{array}{l}\text { Post Observation: Both } \\
\text { TCs join the post } \\
\text { observation Google Meet } \\
\text { to debrief. }\end{array}$ \\
\hline & 2. & $\begin{array}{l}\text { The TC who observed } \\
\text { takes the lead on the post- } \\
\text { observation by offering } \\
\text { three moments of strength } \\
\text { concerning their peer's } \\
\text { teaching and } 3 \text { questions } \\
\text { about their decision } \\
\text { making today. The TC } \\
\text { accesses the email strand to } \\
\text { support these with time } \\
\text { stamps. }\end{array}$ \\
\hline & 3. & $\begin{array}{l}\text { The professor facilitates } \\
\text { this conversation and re- } \\
\text { directs it when needed. }\end{array}$ \\
\hline & 4. & $\begin{array}{l}\text { The TC who taught reflects } \\
\text { on their teaching by } \\
\text { engaging in this } \\
\text { conversation with their } \\
\text { peer. }\end{array}$ \\
\hline & 5. & $\begin{array}{l}\text { Both the TC who observed } \\
\text { and the TC who taught are } \\
\text { asked by the professor to } \\
\text { note three goals they now } \\
\text { have related to the areas of } \\
\text { planning, instruction and/or } \\
\text { assessment for future } \\
\text { teaching experiences. }\end{array}$ \\
\hline 24 Hours Post Observation: & 1. & $\begin{array}{l}\text { The TC who was observed } \\
\text { writes a formal reflection }\end{array}$ \\
\hline
\end{tabular}




\begin{tabular}{|l|l|}
\hline & $\begin{array}{l}\text { related to the experience of } \\
\text { being observed by a peer } \\
\text { and reflects on how they } \\
\text { plan on achieving the goals } \\
\text { they set in the post- } \\
\text { observation conference. } \\
\text { The TC can access the time } \\
\text { stamps from the email } \\
\text { strand once upon request. }\end{array}$ \\
& $\begin{array}{l}\text { 2. } \\
\text { Research must be } \\
\text { connected to one aspect of } \\
\text { this formal reflection. }\end{array}$ \\
\hline Upcoming Week(s) Ahead: & $\begin{array}{l}\text { Both TCs are asked to } \\
\text { share out their experiences } \\
\text { with their other peers } \\
\text { concerning the peer } \\
\text { observation experience. } \\
\text { 2. }\end{array}$ \\
& $\begin{array}{l}\text { Whole cohort reflection } \\
\text { concerning the value of the } \\
\text { peer observation practice } \\
\text { occurs. }\end{array}$ \\
\hline
\end{tabular}

\section{Appendix C}

Observation "Look Fors" and Questions to Guide the Peer Observation Process

\begin{tabular}{|c|c|}
\hline Observation "Look Fors" & Questions for Observation \\
\hline $\begin{array}{l}\text { Creating Positive Virtual Classroom } \\
\text { Environment }\end{array}$ & $\begin{array}{l}\text { 1. How does the TC greet their } \\
\text { students as they enter the } \\
\text { meet? } \\
\text { 2. How does the TC ask how the } \\
\text { students are doing? } \\
\text { 3. How does the TC call on } \\
\text { students by name throughout } \\
\text { their instruction? } \\
\text { 4. How does this TC praise the } \\
\text { students? }\end{array}$ \\
\hline
\end{tabular}




\begin{tabular}{|c|c|}
\hline & $\begin{array}{l}\text { 5. Does the TC control the } \\
\text { conversation today or is there a } \\
\text { balanced ratio of TC talk and } \\
\text { Student Talk? }\end{array}$ \\
\hline Facilitating Virtual Discussions & $\begin{array}{l}\text { 1. Does the TC ask open-ended } \\
\text { questions? } \\
\text { 2. Does the TC allow for wait } \\
\text { time for students to consider } \\
\text { and respond? } \\
\text { 3. Does the TC offer follow-up } \\
\text { questions to encourage } \\
\text { multiple participants? } \\
\text { 4. Does the TC connect prior } \\
\text { knowledge to new content? } \\
\text { 5. Does the TC access the Google } \\
\text { Meet Chat box to inform } \\
\text { follow up questions? } \\
\text { 6. Does the TC access the chat } \\
\text { box to praise students who } \\
\text { respond there as opposed to } \\
\text { accessing their mic? }\end{array}$ \\
\hline $\begin{array}{l}\text { Assessing Students in the Virtual } \\
\text { Classroom by accessing technology }\end{array}$ & $\begin{array}{l}\text { 1. Does the TC access the chat } \\
\text { box to note student responses } \\
\text { other than the student who is } \\
\text { verbally participating? } \\
\text { 2. Does the TC use the chat to } \\
\text { acknowledge these responses } \\
\text { and use them to clarify their } \\
\text { current instruction (ex.-explain } \\
\text { directions again if there are } \\
\text { questions in chat about a } \\
\text { process) } \\
\text { 3. Does the TC vary their use of } \\
\text { instructional platforms to } \\
\text { assess student knowledge (ex.- } \\
\text { Padlet, Jamboards, breakout } \\
\text { rooms, whole group } \\
\text { conversation, chat box } \\
\text { conversation) }\end{array}$ \\
\hline
\end{tabular}




\begin{tabular}{|c|c|}
\hline Other & $\begin{array}{l}\text { 1. Depending on the TC's past } \\
\text { observational data, the } \\
\text { professor can ask that the peer } \\
\text { TC observer note particular } \\
\text { habits their peer has formed. } \\
\text { (ex.- Repeating student } \\
\text { answers but not building off of } \\
\text { these to form follow up } \\
\text { questions, saying "um" "like" } \\
\text { or other words that are fillers) }\end{array}$ \\
\hline
\end{tabular}

*Use these to inform your "in real time" email strand with the peer TC who is observing their peer. The TC can access these in the post-observation conference to help them lead their reflection with their peer who they observed. 